DOI: 10.34015/2523-4552.2020.1.20

УдК 343.8

Бєлкіна Д. С., аспірант кафедри кримінального права та процесу Східноєвропейського національного університету імені Лесі Українки

ORCID: 0000-0003-0759-4705

\title{
ПРАВОВІ КОЛІЗІЇ ТА ПРОГАЛИНИ, ЩО СТОСУЮТЬСЯ ЗМІСТУ ЗАПОБІЖНОЇ ДІЯЛЬНОСТІ У МІСЦЯХ ПОЗБАВЛЕННЯ ВОЛІ
}

У статті, на основі аналізу змісту запобіжної діяльності, що здійснюється у виправних та виховних колоніях, а також у слідчих ізоляторах України, встановлені проблемні питання, що пов'язані із правовим регулюванням даного виду суспільних відносин та реалізацією на практиці законодавчо визначених завдань по запобіганню злочинам і правопорушенням з боку засуджених. Виходячи з цього, в зазначеній статті розроблено низку науково обгрунтованих заходів, спрямованих на подолання правових колізій і прогалин з означеної тематики дослідження.

Ключові слова: колізія; прогалина; запобігання злочинам; сфера виконання покарань.

В статье на основе анализа содержания предупредительной деятельности, осуществляемой в исправительных и воспитательных колониях, а также в следственных изоляторах Украины, установлены проблемные вопросы, связанные с правовым регулированием данного вида общественных отношений и реализацией на практике законодательно определенных задач по предотвращению преступлений и правонарушений со стороны осужденных. Исходя из этого, в указанной статье разработан ряд научно обоснованных мероприятий, направленных на преодоление правовых коллизий и пробелов по указанной тематике исследования.

Ключевые слова: коллизия; пробел; предотвращение преступлений; сфера исполнения наказаний.

Постановка проблеми. Необхідність розгляду даного питання в якості окремого елемента предмета зазначеного дослідження обумовлена декількома обставинами, а саме: 1) закріпленням у ч. 2 ст. 50 КК України такої мети покарання, як запобігання вчиненню нових злочинів засудженими; 2) визначенням такої ж мети у ч. 1 ст. 1 КВК; 3) сучасним станом злочинності, та рівнем правопорушень та інших у сфері виконання покарань України; 4) не обхідністю наукового супроводу та забезпечення тих реформ, що здійснюються у даній галузі державної діяльності; 5) вирішенням проблем, пов'язаних із з'ясуванням змісту по- 
нять «запобігання» та «протидія» злочинності, дискусія щодо яких продовжується у науковій літератуpi; 6) потребою у науковому обгрунтуванні тих розроблених у цій роботі заходів, що стосуються удосконалення правового механізму 3 питань запобіжної діяльності у сфері виконання покарань; 7) завданнями щодо адаптації національного законодавства до законодавства $€ C$, а також приведення правового статусу засуджених до позбавлення волі в Україні до європейський стандартів.

При цьому, варто зазначити, що кожна із приведених вище обставин, має прикладне значення як з огляду дотримання правил юридичної техніки [1, с. 216-220], так і з урахуванням принципів нормотворчості [1, с. $212-$ 214]. Крім цього, важливість цих обставин полягає у тому, що через з'ясування їх змісту можна знайти додаткові аргументи щодо пріоритетності норм матеріального права (у даному випадку - кримінального права) по відношенню процесуальних (процедурних, зокрема - кримінальновиконавчих) норм [1, с. 180-181], а, отже, дати відповідь на питання: який термін слід вживати у законодавчих актах, що стосуються боротьби зі злочинністю - «запобігання» чи «протидія».

Постановка завдання. Саме вказані вище обставини й визначили тему даної наукової статті та її головне завдання - розробити низку науково обгрунтованих заходів, спрямованих на подолання правових колізій і прогалин з означеної тематики дослідження.

Аналіз останніх досліджень i публікацій. Як показали результати вивчення наукової літератури, вивченням правових колізій і прогалин активно займаються такі науковці, як: О. М. Бандурка, В. В. Долежан, О. М. Джужа, О. Р. Дашковська, О. Г. Колб, С. І. Максимов, О. В. Петришин, С. П. Погребняк, А. Х. Степанюк, В. Я. Тацій, М. В. Цвік, С. В. Шевчук та iн.

Поряд $з$ цим, у сфері виконання покарань України означені проблеми досліджені недостатньо, що й стало вирішальним при обранні предмета наукового пошуку у цій статті.

Виклад основного матеріалу. Як встановлено в ході спеціальних наукових досліджень, визначальними й у контексті вимог, що пред'являються до дефініцій (лат. definition - коротке визначення будьякого поняття, яке містить у собі найбільш суттєві його ознаки) [2, c. 191] правового характеру [3, с. 102107], є такі підходи, що пов'язані 3 комплексним вивченням змісту певного виду суспільної діяльності, а також $з$ розробкою науково обгрунтованих шляхів подолання існуючих у зв'язку з цим проблем, з урахуванням тих обставин, що впливають на цей процес.

Якщо звернути увагу на зміст першої із визначених обставин (завдань по запобіганню злочинам з боку засуджених), то слід констатувати, що мета кримінально-виконавчого законодавства дещо не співпадає 3 метою покарання, мова про яку ведеться у ч. 2 ст. 50 КК України. 3окрема, якщо у нормах матеріального права закріплена чітка ціль, заради чого мають застосовуватися їх положення - запобігання злочинам як засудженими, так й іншими особами, то, зокрема, у ч. 1 ст. 1 КВК ця мета дещо звужена - до створення умов для запобігання злочинам, що, як свідчить практика, негативно впли- 
ває на ефективність запобіжної діяльності. Сутність цієї проблеми полягає у тому, що при такому підході адміністрація УВП не несе відповідальності за їі результати, що, у свою чергу, не дозволяє в повній мірі нейтралізовувати, блокувати, усувати тощо детермінанти, які породжують та обумовлюють протиправну поведінку осіб, що відбувають покарання у виді позбавлення волі. 3 іншого боку, закріплений в ч. 1 ст. 1 КВК законодавчий підхід не зобов'язує ДКВС України, його територіальні управління та адміністрацію УВП здійснювати конкретні, реально діючі заходи по запобіганню злочинам та правопорушенням, які $\epsilon$ об'єктивною загрозою для встановленого порядку виконання і відбування покарання у виді позбавлення волі на певний строк, сутність якого полягає в ізоляції засудженого та поміщення його на певний строк до кримінально-виконавчої установи закритого типу (ч. 1 ст. 63 КК України).

Як у зв'язку з цим зробив висновок С. Я. Фаренюк, вираженням ізоляції є саме позбавлення фізичної свободи через поміщення засуджених у місця позбавлення волі на строк, встановлений вироком суду, що передбачає перебування їх на території, що охороняється, обмеження цих осіб у свободі вибору соціального спілкування, їхніх соціально корисних зв'язків з особами, які перебувають на волі, права вільного пересування, вибору місця проживання, характеру і роду занять за своїм розсудом, роздільне тримання різних категорій засуджених, порядок їх спілкування в межах однієї УВП [4, с. 567], що, апріорі (лат. а priori - 3 попереднього; незалежного від досвіду; без перевірки чогонебудь) [2, с. 54] мало б забезпечувати недопущення потрапляння $\mathrm{y}$ місця позбавлення волі заборонених предметів.

У науковій літературі можна зустріти й більш розширене тлумачення терміну «ізоляція», який у широкому змісті розуміють в аспекті двох її взаємозв'язаних видів: фізичної, тобто ізоляції у фізичному аспекті, та духовної (інтелектуальної), яка поєднує в собі соціологічний та соціально-психологічний аспекти [5, c.395]. Остання, на думку учених, проявляється в обмеженні можливостей спілкування, отримання та створення засудженими наукової, культурної та політичної інформації [5, с. 396]. При цьому, закон виходить 3 того, що духовне спілкування засуджених підтримується під час побачень $з$ родичами, близькими, друзями, колегами по колишній роботі на волі тощо, а також у ході зустрічей цих осіб з представниками громад кості та різних її організацій, адвокатами, шляхом листування, одержанням посилок і передач (бандеролей), т. ін. [5, с. 396], що, звичайно, знижує, 3 одного боку, рівень фізичної ізоляції засуджених у місцях позбавлення волі, а, з іншого, створює умови для вчинення ними та іншими особами протиправних діянь.

Отже, цілком очевидним $\epsilon$ y зв'язку з цим висновок про те, що слід не створювати умови для запобігання вчиненню злочинів і правопорушень, як це закріплено в ч. 1 ст. 1 КВК України, а здійснювати контрольні заходи запобіжного характеру по їх недопущенню. 3 огляду цього, та, власне, 3 урахуванням необхідності реалізації на практиці інших змістовних елементів мети 
покарання (кари, виправлення та запобігання тортурам, нелюдському або такому, що принижує гідність, поводження із засудженими, варто у ч. 1 ст. 1 КВК України словосполучення «створення умов» виключити та викласти її в новій редакції.

Додатковим аргументом 3 цього приводу виступають ті статистичні дані про стан і рівень злочинності та правопорушень у місцях позбавлення волі, які склались на протязі 1991-2019 рр. [6, с. 127-156] та свідчать про необхідність більш предметного та цілеспрямованого підходу до організації на нових засадах запобіжної діяльності у цілому $\mathrm{y}$ сфері виконання покарань, та, зокрема, в УВП закритого типу (ч. 3 ст. 11 КВК). Як у зв'язку з цим слушно зауважив С. Я. Фаренюк, ізоляція засуджених до позбавлення волі від суспільства не $є$ абсолютною. Про повну ізоляцію можна говорити лише в тому разі, коли засуджений втратив би будь-який зв'язок із зовнішнім світом, із своїми близькими, з суспільством [4, с. 568], ще раз підтверджує необхідність більш акцентовано та комплексно здійснювати запобіжну діяльність у колоніях та CI30.

Ще на одну особливість запобіжної діяльності у сфері виконання покарань України варто звернути увагу, а саме: іiі нормативно-правове забезпечення здійснюється на підставі лише підзаконних (відомчих) джерел, що суперечить принципу законності, визначеному в ст. ст. 19, 63, 92 Конституції України. Крім цього, у цих актах вживаються одночасно такі терміни, як «запобігання», «профілактика», «протидія» та «попередження», що не тільки не відповідає сучасним зако- нодавчим підходам з означеної проблематики, але й змісту запобіжної діяльності. I, хоча, на переконання А. П. Закалюка, всі зазначені терміни мають загальну змістовну діяльнісну основу, яка пролягає у вчиненні дій для недопущення якогось явища, події, вчинку [7, с. 319]. Разом з тим, як вважає цей науковець, деякі із них мають різне функціональне та отримали на практиці окреме смислове навантаження [7, с. 319]. Зокрема, термін «профілактика» вживається, як у кримінології, так і в нормативно-правових актах як діяльність для недопущення формування, розвитку та реалізації причин і умов злочинності та злочинних проявів загалом [7, с. 319]. Саме у такому сенсі варто розуміти закріплене в ч. 2 ст. 1 КВК словосполучення «профілактика асоціальної поведінки засуджених».

У свою чергу, термін «попередження» вживається у науковій юридичній літературі та у нормативно-правових джерелах у контексті діяльності, що пов'язана з повідомленням про якусь небезпеку (попереджувати про щось) [7, с. 320], хоча, як вірно зазначає А. П. Закалюк, досі ряд авторів ототожнюють його 3 поняттям «запобігання злочинам», вживаючи поряд 3 цим саме термін «попередження» [7, с. 320]. Виходячи 3 цього, навряд чи можна визнати вдалим закріплення у ч. 1 ст. 104 КВК України словосполучення «попередження злочинів» при тому, що варто було б у законі визначити інше та змінити його у цій правовій нормі, а саме - «запобігання злочинам», що в даному випадку було б логічним 3 огляду вимог такого принципу нормотворчості (законотворчості), як системність побудови правових норм, який передбачає забезпечення 
логічної послідовності, узгодженості та збалансованості положень нормативно-правових актів [1, с. 214].

Як показали результати даного дослідження, не менш запитань та дискусій викликає i термін «протидія», який все частіше вживається у наукових працях та у джерелах нормативно-правового характеру (наприклад, у ст. 2 Закону України «Про Національну поліцію». Теоретико-методологічні засади терміну «протидія» обгрунтували у своїх працях 0. О. Бандурка та Л. М. Давиденко [8]. На їх переконання, враховуючи, що розглядувані аналогічні поняття носять переважно кримінологічний характер, слід використовувати об'єднуючий для всіх них термін «протидія злочинності», який включає два аспекти: кримінальноправовий і кримінологічний [8, с. 12]. Зокрема, кримінально-правовий елемент «протидії» складає діяльність правоохоронних органів по виявленню і розслідуванню злочинів, виявленню винуватих осіб та притягнення їх до встановленої законом відповідальності, судовому розгляду кримінальних проваджень, призначенню та виконанню покарань [8, с. 12].

У той самий час, кримінологічний аспект «протидії» утворює діяльність правоохоронних органів по виявленню причин і умов злочинності (криміногенних факторів), їх усунення, ослаблення або нейтралізації [8, с. 12]. Обгрунтовано заперечуючи такий підхід, А. П.Закалюк зазначив, що термін «протидія» в етимологічному смислі тлумачиться як дія, що чинить супротив (рос. наперекор) іншій дії або явищу, а діяльність 3 виявлення причин та умов злочинності у цьому криміно- логічному контексті цього терміну навряд чи етимологічно адекватно відповідає сутності поняття «супротив» [7, с. 322]. Виходячи 3 цього, зазначений науковець зробив висновок про те, що термін «протидія» може бути використаний для відтворення загального впливу на злочинність, але він лише однобічно (у виді «супротиву») відображає останній та не містить однозначної оцінки поняття «запобігання злочинності», тобто не може вживатися як такий, що за сутністю тотожний поняттю «запобігання» навіть у тих випадках, коли він вживається у широкому значенні [7, с. 322].

3 таким підходом слід погодитись, якщо в основу покласти теорію запобігання злочинності та етимологічне значення слова «запобігання». У тлумачних словниках термін «запобігання» означає не допускати, заздалегідь відвертати що-небудь неприємне, небажане [9, с. 267]. У науковій літературі під запобіганням злочинності розуміють різновид суспільної соціально-профілактичної діяльності, функціональний зміст та мета якої полягає у перешкоджанні дії детермінантів злочинності та ії проявів, передусім причин і умов останніх через обмеження, нейтралізацію, а за можливістю усунення їхньої дії [10, c. 305]. У свою чергу, один із сучасних вітчизняних розробників теорії запобігання злочинності В.В.Голіна вивів таке його визначення - це соціальна політика держави, спрямована на подолання кримінально небезпечних протиріч у суспільних відносинах 3 метою їх позитивного вирішення i поступового витиснення (так зване загальносоціальне запобігання), а також спеціальна випереджальна практика протидії формуванню і реа- 
лізації на різних стадіях злочинних проявів (спеціально-кримінологічне запобігання) [11, с. 16]. При цьому, у структурі спеціально-кримінологічного запобігання злочинності (яке складає у цій роботі зміст предмета дослідження) він виокремив наступні елементи: 1) кримінологічну профілактику; 2) відведення злочинів; $3)$ припинення злочинів [11, с. 22].

Кримінологічна профілактика, на його думку, - це сукупність заходів щодо завчасного виявлення та усунення негативних явищ, які виникли і детермінували злочинність або окремі її видів [12, с. 144]. Виходячи 3 цього, В. В. Голіна обгрунтував такі види кримінологічної профілактики: а) профілактику випередження, під якою він розуміє таку запобіжну діяльність спеціалізованих суб'єктів, що спрямована на недопущення виникнення i поширення криміногенних явищ i процесів у суспільному житті [11, с. 24]; б) профілактику обмеження, яка передбачає вжиття таких запобіжних заходів, що перешкоджають поширенню в країні, регіоні або місті кримінальних явищ, детермінації окремих видів злочинності та формування типових рис різних категорій злочинців $[11$, с. 26]; в) профілактику усунення, яка визначає таку діяльність суб'єктів, яка послабляє або ліквідує негативні явища та процеси, що активізують злочинні прояви злочинності [11, с. 27]; г) профілактику захисту, яка розглядається як сукупність заходів, що здійснюються з метою ліквідації умов, які сприяють виникненню злочинних проявів, та (опосередковано) антигромадських поглядів [11, с. 29].

Щодо змісту другого елемента кримінологічного запобігання зло- чинності - відвернення злочинів, то його сутність проявляється у здійсненні сукупності спеціальнокримінологічних заходів запобіжного характеру, спрямованих на окремі групи та конкретних осіб, які виношують злочинні наміри, замислюють вчинення злочинів і позитивно сприймають злочинний спосіб життя, 3 метою дискредитування злочинної поведінки, добровільної відмови від злочинної мотивації та наміру або продовження злочинної діяльності [11, с. 144]. При цьому, у структурі цього напряму запобігання злочинності науковці виокремлюють: 1) заходи переорієнтації антисуспільної настанови (спеціальні економічні та соціально-психологічні програми; заходи, спрямовані на формування у громадян антикримінологічної культури; кримінальна поінформованість населення; організаційно-правові заходи; т. ін.) [12, c. 145]; 2) активні контрзаходи, а саме: переконання; застосування різних форм примусу; застереження (попередження); надання допомоги для осіб, звільнених з УВП закритого типу [12, с. 145].

Крім цього, В. В. Голіна у змісті запобіжної діяльності по відведенню злочинів виокремлює: а) заходи загального відвернення злочинів, під якими він пропонує розуміти сукупність спеціальних заходів, спрямованих на певне коло або групу осіб щодо усунення або нейтралізації їх злочинних намірів, добровільної відмови від злочинної поведінки [11, c. 31-32]; б) заходи індивідуального відвернення злочинів, сутність яких проявляється через специфічний комплекс заходів, які здійснюються різними суб'єктами запобіжної діяльності, щодо осіб, про яких достові- 
рно відомо, що вони замислюють вчинення злочинів з метою активного втручання і впливу на свідомість, волю, поведінку та спосіб життя [11, c. 32].

Як показали результати даного дослідження, не менш специфічними по змісту та спрямованості $€$ й заходи, які здійснюються у межах третього елементу кримінального запобігання - діяльністю по припиненню злочинних проявів, під якою в науці розуміють сукупність видів діяльності по недопущенню завершення розпочатого злочину шляхом розроблення і здійснення спеціальних заходів [12, с. 145] (у даному випадку мова ведеться про запобігання вчиненню злочинів на стадії готування та замаху на вчинення злочину (ст. ст. 13-15 КК)). Структурну зазначений елемент кримінологічного запобігання передбачають наявність: 1) заходів спонукання, які здійснюються 3 метою досягнення відмови кримінальної особи (осіб) від продовження злочинної діяльності («тактика переляку»); спонукання до добровільної відмови від вчинення злочину (ст. 17 КК); проведення різних заходів у межах ОРД; та ін. [11, с. 38]; 2) заходів перестереження (обережності), які застосовуються для того, щоб створити умови, які виключають можливість чи перешкоджають продовженню розпочатої злочинної діяльності (обладнання об'єктів права власності сигналізацією; засобами відеоспостереження; посилення охорони шляхом залучення додаткових сил; т. ін.) [11, с. 38-39]; 3) заходів активного втручання, які передбачають негайну реакцію відповідних правоохоронних органів у разі, якщо зволікання може призвести до безпосереднього злочинного посягання (як от: затримання злочинця; проведення аудиту; огляд нежилих приміщень; т. ін.) [11, c. 39].

Як показали результати вивчення наукової літератури, кримінологи, крім зазначених, виокремлюють та обгрунтовують й інші критерії поділу на групи (види) заходи кримінального запобігання.

Висновки. Таким чином, проведений аналіз усіх ознак поняття «запобігання злочинам у сфері виконання покарань» дає підстави стверджувати, що вони мають системний взаємозв'язок поміж собою, не дивлячись на те, що кожна із них має свої особливості, специфіку та процедуру реалізації у запобіжній діяльності, а також на те, що кожна із них забезпечується різними правовими джерелами, для яких характерними $€$ на сьогодні правові колізї̈, недоречності і прогалини, що мають бути вирішені на нормативно-правовому рівні, $з$ урахуванням сучасних доктринальних підходів, завдань тих реформ, що проводяться у зазначеній сфері суспільних відносин, а також вимог міжнародно-правових актів, згоду на які надала Верховна Рада України.

\section{Список використаних джерел}

1. Теорія держави і права : підручник для студ. юрид. вищ. навч. закл. / О. В. Погребняк, В. С. Смородинський та ін.; за ред. О. В. Петришина. Харків : Право, 2014. 368 c.

2. Булыко А. Н. Большой словарь иностранных слов. 35 тысяч слов. Изд. 3-е, испр., перераб. Москва : Мартин, 2010. 704 с. 
3. Тростюк 3. А. Вимоги до термінологічного апарата Основної частини КК України та їх загальна характеристика. Проблеми пенітенціарної теорії та практики. 2001. №6. С. 102-107.

4. Фаренюк С. Я. Поняття режиму та його основні вимоги. Кримінальновиконавче право / за заг.ред. д.ю.н., проф. О. М. Джужи. Київ : Атіка, 2010. С. 564-579.

5. Гель А. П., Семаков Г. С., Яковець І. С. Кримінально-виконавче право України: навч. посібник / за ред.проф. А. Х. Степанюка. Київ : Юрінком Інтер, 2008. 624 с.

6. Запобігання злісній непокорі вимогам адміністрації установи виконання покарань: навч. посіб. / Боровик А. В., Колб О. Г., Копотун I. М. та ін. ; за заг. ред. д.ю.н., проф. О. Г. Колба. Луцьк : СПД Гадяк Ж. В.; друкарня «Волиньполіграф», 2020. 320 с.

8. Закалюк А. П. Курс сучасної української кримінології : теорія і пркатика у 3-х кн. Кн. 1 : Теоретичні засади та історія української кримінологічної науки. Київ : Видавничий Дім «Ін Юре». 2007. 424 с.

9. Давиденко Л. М., Бандурка А. А. Противодействие преступности: теория, практика, проблемы: монография. Харьков : Изд-во Нац. ун-та внутр. дел, 2005. 302 с.

10. Словник української мови в 11 томах. Київ : Наука, 1972. Т. 3. 768 с.

11. Кримінологія. Загальна частина. Альбом схем / Автори-упорядники: С. Ф. Денисов, Т. А. Денисова, С. Г. Кулик, О. С. Шеремет. Чернігів : ПАТ «ПВК «Десна», 2015. $658 \mathrm{c.}$

12. Голіна В. В. Запобігання злочинності (теорія і практика) : навч. посіб. Харків : Нац. юрид. акад. України, 2011. 120 с.

13. Голіна В. В. Поняття і система запобігання злочинності, класифікація запобіжних заходів. Кримінологія: підручник / за ред. В. В. Голіни та Б. М. Головкіна. Харків : Право, 2014. С. 142-148.

\section{References}

Petryshyn, 0., Pohrebniak, V. (2014). Teoriia derzhavy i prava. Kharkiv: Pravo [in Ukrainian].

Bulyko, A. N. (2010). Bolshoi slovar ynostrannykh slov. 35 tysiach slov. Yzd. 3-e, yspr., pererab. Moskva [in Russian].

Trostiuk, Z. A. (2001). Vymohy do terminolohichnoho aparata Osnovnoi chastyny KK Ukrainy ta yikh zahalna kharakterystyka. Problemy penitentsiarnoi teorii ta praktyky, 6, 102107 [in Ukrainian].

Fareniuk, S. Ya. (2010). Poniattia rezhymu ta yoho osnovni vymohy. Kryminalnovykonavche pravo. Kyiv: Atika [in Ukrainian].

Hel, A. P., Semakov, H. S., Yakovets, I. S. (2008). Kryminalno-vykonavche pravo Ukrainy. Kyiv; Yurinkom Inter [in Ukrainian].

Borovyk, A. V., Kolb, O. H., Kopotun, I. M. (2020). Zapobihannia zlisnii nepokori vymoham administratsii ustanovy vykonannia pokaran. Lutsk [in Ukrainian].

Zakaliuk, A. P. (2007). Kurs suchasnoi ukrainskoi kryminolohii : teoriia i prkatyka u 3 $k h k n$. Kn. 1. Teoretychni zasady ta istoriia ukrainskoi kryminolohichnoi nauky. Kyiv: Vydavnychyi Dim «In Yure» [in Ukrainian].

Davydenko, L. M., Bandurka, A. A. (2005). Protyvodeistvye prestupnosty: teoryia, praktyka, problemy. Kharkov: Yzd-vo Nats.un-ta vnutr. Del [in Russian].

Slovnyk ukrainskoi movy v 11 tomakh. Kyiv: Nauka, 1972. T. 3 [in Ukrainian].

Denysov, S. F., Denysova, T. A. (2015). Kryminolohiia. Zahalna chastyna. Albom skhem. Chernihiv: PAT «PVK «Desna» [in Ukrainian].

Holina, V. V. (2011). Zapobihannia zlochynnosti (teoriia i praktyka). Kharkiv: Nats.yuryd.akad. Ukrainy [in Ukrainian]. 
Holina, V. V. (2014). Poniattia i systema zapobihannia zlochynnosti, klasyfikatsiia zapobizhnykh zakhodiv. Kryminolohiia. Kharkiv: Pravo [in Ukrainian].

D. Belkina, Postgraduate student of department of criminal law and process East European national university named of Lesya Ukrainka

ORCID: 0000-0003-0759-4705

\section{The legal collisions and gaps concerning the content of safety activity in places of detention}

The need to consider this issue as a separate element of the subject of the study is due to several circumstances, namely: 1) securing in Part 2 of Art. 50 of the Criminal Code of Ukraine such purpose of punishment as prevention of committing new crimes by convicted persons; 2) defining the same goal in Part 1 of Art. 1 KVC; 3 ) the current state of crime, and the level of offenses and others in the sphere of punishment of Ukraine; 4) the need for scientific support and provision of those reforms that are being carried out in this field of state activity; 5) solving problems related to clarifying the content of the concepts of "prevention" and "counteraction" to crime, which are discussed in the scientific literature; 6) the need for scientific substantiation of the measures developed in this work concerning the improvement of the legal mechanism on preventive activities in the sphere of punishment; 7) the tasks of adapting national legislation to EU legislation, as well as bringing the legal status of prisoners in Ukraine to European standards.

At the same time, it should be noted that each of the above circumstances is relevant both in terms of compliance with the rules of legal technology and in accordance with the principles of rulemaking. In addition, the importance of these circumstances is that by clarifying their content, one can find additional arguments regarding the priority of substantive law (in this case - criminal law) over procedural (procedural, in particular - criminal) norms, and, therefore, to answer the question: what term should be used in legislation relating to the fight against crime - "prevention" or "counteraction". It is the above mentioned circumstances that have defined the topic of this scientific article and its main task is to develop a series of scientifically sound measures aimed at overcoming legal conflicts and gaps in the specified subject of research.

Keywords: collision; gap; prevention of crimes; sphere of execution of punishments. 